\title{
Relationship between scolex, shape of the cyst and timing of surgery in subretinal cysticercosis
}

\author{
Subhakar Reddy (ㄷ), Bhavik Panchal 지 , Avinash Pathengay
}

Vitreoretina and Uveitis Services, LV Prasad Eye Institute, GMRV Campus, Visakhapatnam, India

\section{Correspondence to} Dr Bhavik Panchal; drbhavikpanchal@gmail.com

$\mathrm{SR}$ and $\mathrm{BP}$ are joint first authors.

Accepted 31 July 2020

Check for updates

(c) BMJ Publishing Group Limited 2020. No commercial re-use. See rights and permissions. Published by BMJ.

To cite: Reddy S, Panchal B, Pathengay A. BMJ Case Rep 2020;13:e236805 doi:10.1136/bcr-2020236805

\section{DESCRIPTION}

A 31-year-old woman presented with right eye sudden loss of vision of 15 days duration. On examination, the best corrected visual acuity was $20 / 600$ in the right eye and 20/20 in the left eye. Bilateral anterior segment examination was normal. Right eye fundus showed hazy media due to vitritis (grade 2), with a thin subretinal translucent cyst attached to optic disc with bright white spot (scolex) at its edge, suggestive of subretinal cysticercosis (figure 1A). Left eye fundus was unremarkable. There was history of eating undercooked pork. She was started on oral anti-helminthics and oral steroids. She underwent pars plana vitrectomy with in toto removal of cyst. Neuroimaging ruled out any intracranial cysticercosis.

When the patients serial fundus photographs at day 3 (figure 1B), 1 week (figure 1C) and 2 weeks (figure 1D) were reviewed, an interesting observation was noted; when the scolex was present at the edge of the cyst, it was fixed and formed an irregular oval shape (figure 1A-C) but when the scolex was at the centre of the cyst, it was mobile and formed a perfect sphere (figure 1B-D). Also, the overlying retinitis (red arrow) clearly demarcated the path travelled by the cyst.

Cysticercosis is a parasitic infestation caused by larval form of cestode tapeworm Taenia solium. It is considered endemic in India. ${ }^{1}$ The parasite may get access to posterior segment of the eye through the choroidal circulation and reaches subretinal space. The larvae may stay there itself (subretinal) or reaches vitreous cavity after perforating through overlying retina. ${ }^{2}{ }^{3}$ The diagnosis of intraocular cysticercosis is mainly clinical where a live cyst can be seen as a translucent white cyst in the vitreous cavity or subretinal space. Differentials include non-pigmented vitreous cyst, Coats disease, diffuse unilateral subacute neuroretinitis and hydatid cyst. On illumination with bright light, cyst wall may show undulating movements due to mobile scolex. The vitality of parasite is established by looking at undulating movements of scolex, periodic evagination of scolex, motility of the cyst and postoperative examination of parasite. ${ }^{4}$ However, the relationship between the scolex and shape of cyst has not been reported prior in the literature.

We observed, the spherical shape corresponds to a free-floating mobile cyst and the oval shape relates to a fixed cyst. Possible explanation is when the scolex is fixed at one end, it pushes the intracystic fluid to opposite end making it oval and when the scolex is in the centre, intracystic fluid is distributed all around it making it spherical. A free-floating

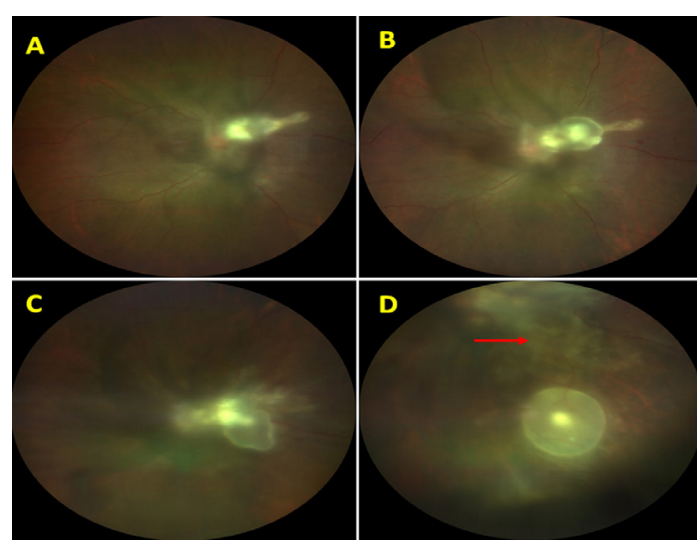

Figure 1 Serial fundus photographs at day $1(A)$, day 3 (B), 1 week (C), 2 weeks (D) showing changing shape of cyst with position of scolex. (D) Overlying retinitis through which the cyst has travelled (red arrow).

mobile cyst in subretinal space can migrate transretinally into the vitreous cavity. Thus, knowing the shape of cyst may help in better surgical planning and avoiding intraoperative mishaps. This may help in surgical planning of the cyst removal, as a fixed cyst is easier to locate and remove compared with a free-floating mobile one.

\section{Patient's perspective}

I live in a village. In my village, hand and food hygiene may not be adequately practised. Initially I was scared that a live worm was present in my eye. However, now I'm relieved that it was removed completely after surgery. I will be vigilant from now and also consider educating people surrounding my village about adequate hygienic practices and food habits from now on.

\section{Learning points}

- Human cysticercosis, a preventable cause of blindness, occurs when Taenia solium eggs are ingested via faecal-oral transmission from a tapeworm host.

- In cases of intraocular cysticercosis, neuroimaging helps rule out intracranial spread.

- The shape of the subretinal cysticercosis may change with position of scolex. When the scolex is in the centre, the cyst assumes a spherical shape and when it is at one end it assumes an irregular oval shape. 


\section{Twitter Bhavik Panchal @bhavikpanchal87}

Contributors SR: initial preparation of the entire manuscript and compilation of contributions from other authors, and reviewed the requirements and guidelines for submission and designed the template accordingly, extensive literature search of similar cases. BP: contributed in establishing the diagnosis and management of the patient as a retina consultant, writing the case presentation, revision of the manuscript, citation management and editing of images. AP: served as the chief of the division and supervised all the authors, set-up the timeline for submission, planning the submission to $B M J$, reviewed the requirements, critical revision of the article at every stage, drafted the take-home messages and gave final approval of the version to be submitted.

Funding HERF - Hyderabad Eye Research Foundation.

Competing interests None declared.
Patient consent for publication Obtained.

Provenance and peer review Not commissioned; externally peer reviewed.

\section{ORCID iDs}

Subhakar Reddy http://orcid.org/0000-0001-5683-7334

Bhavik Panchal http://orcid.org/0000-0001-8594-6126

\section{REFERENCES}

1 David S, Mathai E. Ocular cysticercosis--a review of 25 cases. J Assoc Physicians India 2000:48:704-7.

2 Bartholowmew RS. Subretinal cysticercosis. Am J Ophthalmol 1975;79:670-3.

3 Dhiman R, Devi S, Duraipandi K, et al. Cysticercosis of the eye. Int J Ophthalmol 2017:10:1319-24

4 Lech J. Ocular cysticercosis. Am J Ophthalmol 1949;32:523-48.

Copyright 2020 BMJ Publishing Group. All rights reserved. For permission to reuse any of this content visit https://www.bmj.com/company/products-services/rights-and-licensing/permissions/

BMJ Case Report Fellows may re-use this article for personal use and teaching without any further permission.

Become a Fellow of BMJ Case Reports today and you can:

- Submit as many cases as you like

- Enjoy fast sympathetic peer review and rapid publication of accepted articles

- Access all the published articles

Re-use any of the published material for personal use and teaching without further permission

Customer Service

If you have any further queries about your subscription, please contact our customer services team on +44 (0) 2071111105 or via email at support@bmj.com.

Visit casereports.bmj.com for more articles like this and to become a Fellow 